\title{
THE IMPACT OF THE COVID-19 PANDEMIC ON PRICE DISPARITIES AND FLUCTUATIONS OF SHALLOTS IN TRADITIONAL MARKETS
}

\author{
Nendissa Doppy Roy*, Olviana Tomycho, Kapioru Charles \\ Department of Agribusiness, Faculty of Agriculture, University of Nusa Cendana, Indonesia \\ *E-mail: roynendissa@staf.undana.ac.id
}

\begin{abstract}
Horticultural food commodities such as shallots are a staple and strategic commodity in Indonesia which is affected by the covid-19 pandemic situation. This study is to answer the pattern of price movements and disparities, as well as the level of fluctuations in the price of shallots due to the covid-19 pandemic in traditional markets in Kupang and Surabaya. Kupang NTT as the recipient of shallots supplies from Surabaya, East Java. Using timeseries data of the shallot prices for the period of June 2016 - March 2020 to see disparities and fluctuations, which analyzed using graphics and coefficient of variation (CV). The results of the analysis found that the disparity and fluctuations of the price of shallots between the periods of June 2016 - March 2020, showed a movement that continues to increase, but with a fluctuating increase. Price disparity and fluctuation in Kupang is higher than in Surabaya. This difference is in addition to the seasonal factor also because Surabaya is one of the main suppliers of shallots to Kupang. So that the prices sensitively will rise if there is a disruption in distribution (supply). This seems clear when the initial enactment of social distancing and panic buying took place. Market operations and policies to improve efficiency in the distribution of trade in goods need attention.
\end{abstract}

\section{KEY WORDS}

Shallots, covid-19 pandemic, disparity, price fluctuations.

Shallots are important commodities that are widely traded in Asia and the world. Growth of shallot production in the world shows an increasing trend since 2005-2014 with a growth rate of 3.4\% per year (Ministry of Trade of RI 2018). Data from Food and Agriculture Organization (FAO), shallots in the world produced by 143 countries. China is the world's largest shallots producer $(26.88 \%)$, followed by India (18.81\%). Indonesia is among the top ten shallots producing countries in Asia, besides China and India ranking first and second in the period 2005-2014. At the same time, the highest shallots harvest area was Indonesia, making it one of the ten onion exporting countries. So that the need for shallots in Indonesia both for consumption and export shows an increasing trend every year.

The need for shallots in Indonesia increases every year because the number of industries made from shallots increases. The daily consumption habits of Indonesian people using shallots as a seasoning in every dish also increased. This makes shallots classified as a national food strategy because it has high economic value. The slightest disruption in supply and demand will affect the price fluctuations and can contribute to inflation.

BPS data shows that between 2013-2015, disparities and fluctuations in the price of shallots occurred as shown in Figure 1. The highest fluctuations occurred in 2013, then relatively stable in 2014 and slightly moved up and down in 2015 . The pattern of monthly price movements in 2016 - 2019, is likely to show a relatively similar pattern. Price fluctuations are more influenced by seasonal or climatic factors and the presence of religious holidays.

Shallots production in Indonesia continues to increase every year with varying increases numbers. In 2016 production increased by $4.4 \%$ from the previous year and 2017 is estimated to increase by $3.13 \%$. Indonesian Ministry of Agriculture's Pusdatin Report (2017), the demand balance (consumption + export) of shallots from 2006-2017 shows a positive value with a fluctuating amount. But with the covid-19 pandemic that hit the world today has caused disruption to the supply and demand of shallots in Indonesia and the 
world. This disturbance is increasingly difficult in regions that experience a production deficit such as in the Province of East Nusa Tenggara (NTT). Generally NTT receives a supply of shallots from East Java Province which is distributed through of Surabaya. East Java is the largest shallots producer in Indonesia after Central Java. Changes in prices that occur to the production area will have an impact on the consumption area.

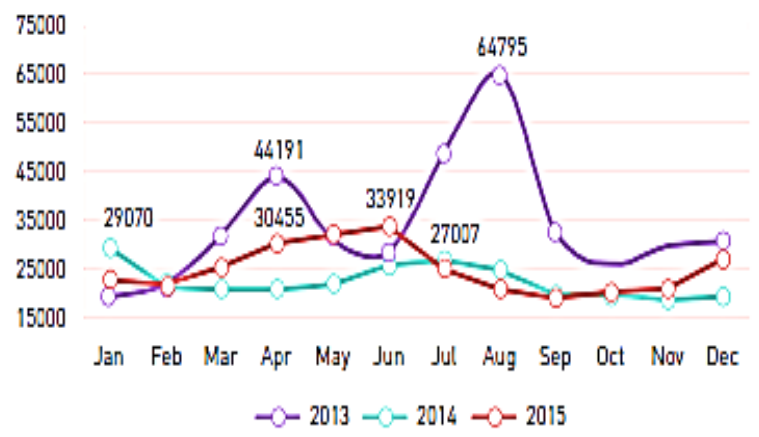

Figure 1 - Shallot Monthly Prices in 2013-2015 (Source of BPS, 2017, processed)

The research studies about the impact of the Covid-19 pandemic on social- economic aspects of the world, Nicola et al. (2020) shows that the Covid-19 pandemic has sparked fears of an impending economic crisis and recession. Social distancing, self-isolation and travel restrictions have lead to reduced workforce across all economic sectors and caused many jobs to be lost, commodities and manufactured products have decreased, medical supplies have significantly increased, food sector is also facing increased demand due to panic -buying and stockpiling of food products, besides that Chetty et al. (2020) about How did co-19 and stabilization policies affect spending and employment? a new real-time economic tracker based on private-sector data, Buheji et al. (2020) about the extent of the covid-19 pandemic socio-economic impact on global poverty. a global integrative multidisciplinary review, Norouz et al. (2020) about pandemics impact economies and climate change: Exploring the impacts of covid-19 on oil and electricity demand in China, Chang \& Meyerhoefer, (2020), research on Covid-19 and the Demand for Online Food Shopping Services: Empirical Evidence from Taiwan.

The impact of pandemic covid-19 on world food is symptomatic of a number of agricultural economic indicators, such as employment, production, and farm household income. The pandemic Covid-19 certainly had wide-ranging impacts on various sectors not just the agricultural sector.

This study focuses on the covid-19 pandemic had an impact on the production, consumption and distribution of shallots among cities and provinces in Indonesia. This has a negative impact on the price of shallots in the market, especially in traditional markets. Traditional markets in Indonesia are very sensitive to strategic food commodity price fluctuations. The slightest disruption in supply or demand, prices immediately change up or down. There have not been many studies found in traditional markets and compare the impact of the covid-19 pandemic on disparity and price fluctuations between cities that supply shallots and cities that receive supplies.

This paper would like to see how the impact of the covid-19 pandemic on the price disparity and fluctuations in the monthly price of shallots on traditional markets in two provincial cities, namely Kupang and Surabaya. This research will contribute to policy making and market participants to avoid the risk of price volatility.

\section{METHODS OF RESEARCH}

This study uses time-series data for the monthly price of shallots from June 2016 to April 2020 sourced from the Strategic Food Price Information Center in traditional markets in two provinces, namely Kupang and Surabaya. Kupang is a recipient of shallots because it is always deficit, while Surabaya is a supplier (surplus area). Traditional markets are the object 
of observation because in Indonesia the commodities traded are very sensitive to price fluctuations if there is little supply or demand disruption.

To measure disparity using graphical analysis and price fluctuations in the cities of Kupang and Surabaya in traditional markets using the coefficient of variation (CV). CV illustrates the price variability expressed in percentage (\%). The smaller the CV, the lower the level of price fluctuations and vice versa. Mathematically formulated:

$$
\begin{gathered}
C V=\frac{S D}{\text { Mean }} \\
S D=\sqrt{ } \frac{\Sigma(X-x)^{2}}{n}
\end{gathered}
$$

Where: $\mathrm{CV}=$ coefficient of variance; $\mathrm{SD}=$ standard deviation of prices; Mean = mean price; $\mathrm{X}=$ price changes; $\mathrm{x}=$ average price change; $n=$ average amount of price.

The Indonesian Ministry of Trade uses a CV to measure the level of fluctuation and inflation in Indonesia. to moderate price fluctuations if the CV is between $5-9 \%$ and high fluctuations if the CV is> 9\% (Kemendang RI 2015); and Nendissa, et al. 2018).

\section{RESULTS AND DISCUSSION}

Distribution Patterns of Shallot Trade: NTT and East Java. The results of a survey conducted by the Indonesian Central Bureau of Statistics (BPS, 2018), found a pattern of shallots distribution in NTT. Distribution from farmers to end consumers involves collectors, wholesalers, and retail traders. The distribution pattern of shallot trade in NTT can be seen in Figure 2.

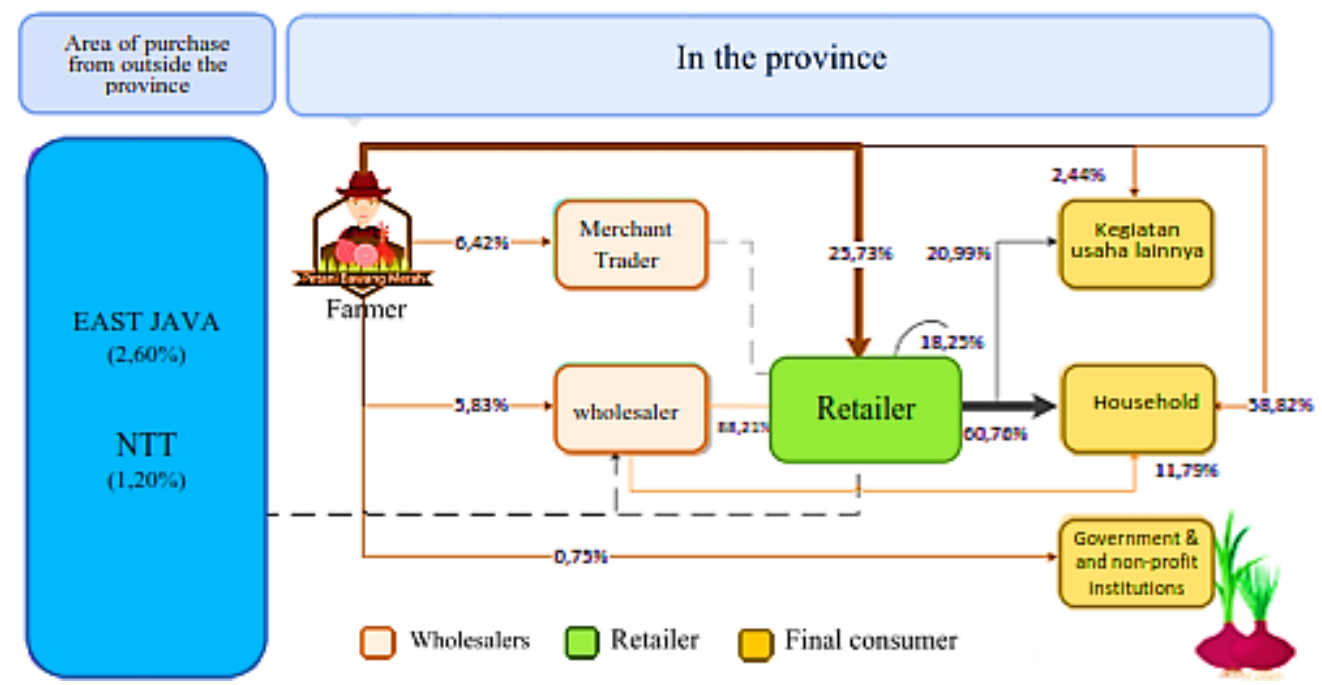

Figure 2 - Distribution pattern of shallot trades in 2018 in NTT Province (Source: BPS. 2018)

Shallots production by NTT farmers amounted to $58.82 \%$ is directly distributed to households and $25.73 \%$ to retailers, the rest is to merchant collectors $(6.42 \%)$, to wholesalers $(5.83 \%)$, to non-profit governments $(0,75 \%)$ and for other business activities $2.44 \%$, (BPS, 2018). In another illustration, the retailer gets a supply of shallots from the merchant trader. Retailers sell most of the shallots to households $(60.76 \%)$ other business activities (20.76\%) the rest are sold to fellow retailers.

The pattern of shallots distribution in East Java based on the results of a survey conducted by BPS (2018), found from farmers to end consumers, involving several business units, namely: 
Shallot farmers in East Java Province directly distributed $43,11 \%$ of their production outside the province. The remaining $28,49 \%$, distributed through the processing industry, to retail traders $(14,31 \%)$, to merchant collectors $(13,18 \%)$, to wholesalers $(0,88 \%)$ and to households $(0,02 \%)$. Furthermore, most from the retail traders were distributed to households by 98,29 percent and the rest were distributed to fellow retail traders.

The distribution pattern of the NTT shallot trade distribution is shorter than East Java, because marketing agencies involved in distribution are less in NTT than in East Java. Most of the shallots produced by farmers in NTT $(58,82 \%)$ are distributed directly to households in the province. Then $25,73 \%$ to retailers, the rest to merchant collectors $(6,42 \%)$, wholesalers $(5,83 \%)$, non-profit governments $(0,75 \%)$ and for other business activities by $2,44 \%$, (BPS, 2018).

In another illustration, the retailer gets a supply of shallots from the merchant collectors. Retailers sell most of the shallots to households $(60.76 \%)$, to other business activities $(20.76 \%)$, the rest is sold to fellow retailers. This distribution pattern occurs because collectors get a lot of supply of shallots from outside NTT including from Surabaya.

In contrast to the distribution pattern of shallot trade in East Java, namely $43,11 \%$ of its production is distributed outside the province of East Java and $28,49 \%$ to the processing industry made from shallots. Then distributed to retail traders $(14,31 \%)$, merchant collectors $(13,18 \%)$. Only a small portion of the remainder is distributed to wholesalers $(0,88 \%)$ and $0,02 \%$ directly to the household. Distribution to the processing industry is quite high whereas in NTT there was no distribution to the processing industry.

Trading and Transportation Margins (MPP). MPP is a benefit received at the level of food distribution from upstream to downstream. MPP at the same time illustrates the difference between the sale value and the purchase value which includes the cost of transporting shallots.

The survey results found that the shallots MPP of East Java Province in 2017 was quite high at $59,69 \%$, exceeding the national MPP of $49,06 \%$, (BPS, 2018). This indicates that the price disparity at the farmer level and at the end consumer is very large. Compared to MPP shallots in NTT are relatively small at $30,75 \%$ in the same year. An MPP value is probably caused by three things: first, the distribution chain of the number of marketing institutions involved; secondly, differences in transportation costs and thirdly, different profit taking among distribution agencies due to market mechanisms.

The pandemic Covid-19, which began to be felt in January 2020 throughout the world, has hampered the distribution of goods trading systems, especially since the implementation of social distancing. As a result of restrictions on all activities outside the home, many job cuts, causing shock in the supply and demand for food commodities including shallots. Pressure is not only on the supply side but also on demand side. One of the biggest pressures is the decline in food consumption (shallots) because many industries made from shallots and restaurants and hotels are closed. This condition has an impact on the price volatility of shallots, because production is not distributed on the other hand the demand drops dramatically. But at the beginning of the pandemic there was an increase in consumption of some ready-to-eat food commodities due to panic buying, causing a scarcity of goods which resulted in an increase in uncontrolled prices.

Shallot Price Disparity. Price disparity is the difference in the price of shallots in each time period. The Kupang as the recipient of supply and Surabaya as the shallot supplier. Figure 3 illustrates that the trend of price movements of shallots during the period of July 2016 - March 2020 in both cities shows the same variation pattern of movement. While the price level shows a variable movement with a fairly high level of price disparity. The period between September 2016 and January 2017 showed the opposite price movement between Kupang (highest price) and Surabaya price (low), which was caused by supply constraints. Basically, every agricultural commodity has its own price movement cycle (Fakari, et al. 2013), because agricultural commodities have their own uniqueness compared to nonagricultural commodities. Agricultural commodities are commodities whose supply are influenced by seasons (weather and climate). So that the price of agricultural commodities tends to fluctuate (Dambe, et al 2019; Rayhan, et al. 2019). 


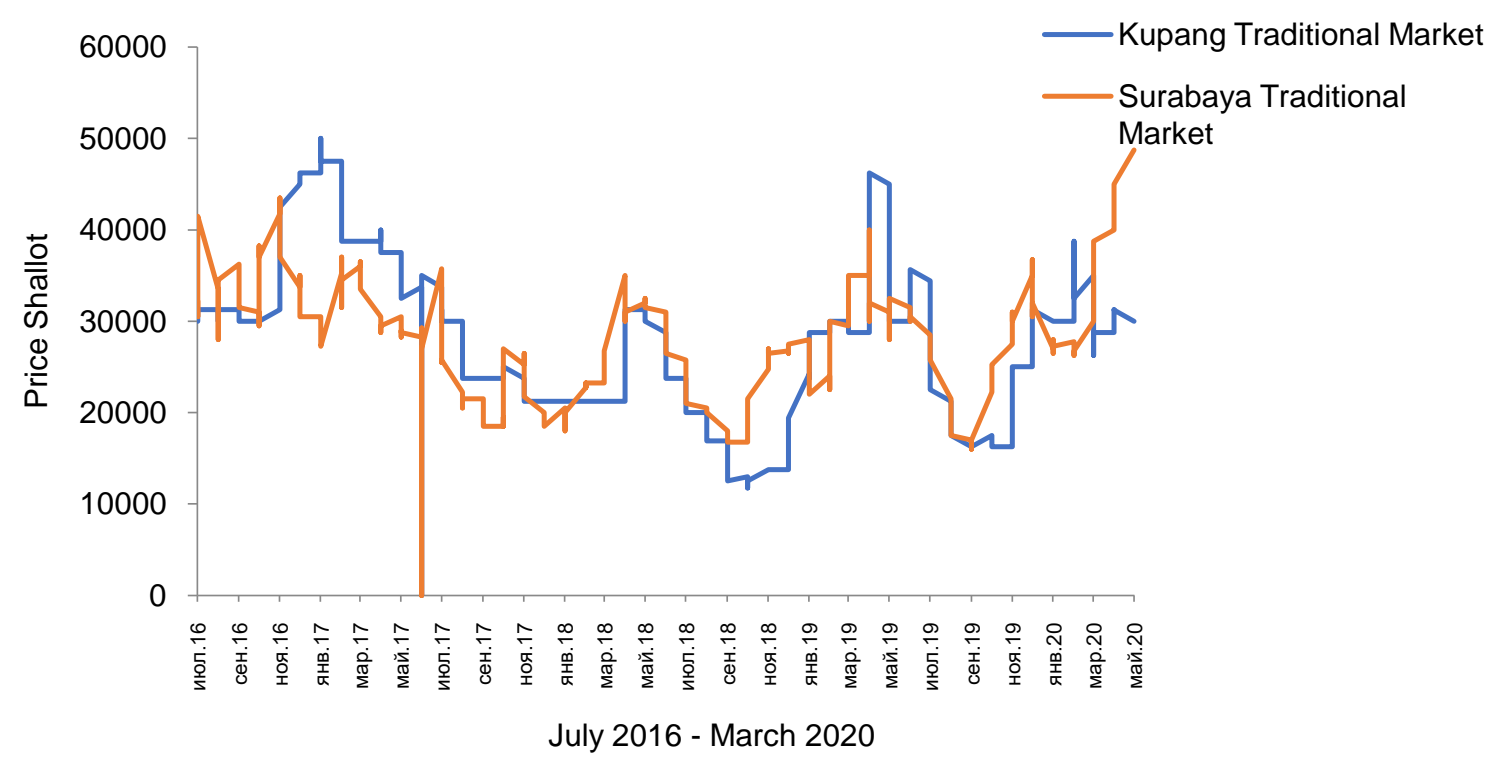

Figure 3 - Disparity in the monthly price of shallots in the period of July 2016-March 2020 at the Kupang and Surabaya traditional markets

The trend of the price movement of shallots in the period 2018 increased between March - June 2018 then dropped dramatically its peak in August - December 2018. Likewise, in the 2019 period increased very sharply in April - June 2019 then decreased in August November 2019. This price movement cycle follows changes in seasons (climate) and changes in planting and harvest seasons, so that the prices follow the principles of market mechanisms (supply and demand).

Price movements that occur entering 2020, in the pandemic Covid-19, followed by restrictions on the movement of people and goods in all sectors of the economy (Bonaccorsi et al., 2020; Ozili \& Arun, 2020; Barua, 2020; Douglas et al., 2020). Then the need for agricultural commodities began to be disrupted, resulting in panic buying. Large purchases of food products occur in the market, both traditional and modern markets. As a result, prices have suddenly risen, including the price of shallots. This can be seen in the late JanuaryMarch 2020 period, the price of shallots in Surabaya rose very high (Figure 3), due to transportation and distribution disruptions due to social restrictions on the impact of the pandemic Covid-19. Whereas prices in Kupang move up in January 2020 then drop in March.

Shallots Price Fluctuations. The development of world shallot prices in several decades continues to increase accompanied by increasing the price fluctuations. This is marked by an increase in CV from 16\% in the period of 1961-1972 to $25 \%$ in the period of $1973-1994$, increasing again to $27 \%$ in the period of $1995-2011$ (FAOSTAT quoted by the Ministry of Trade of Republic of Indonesia 2017). This increase shows that horticultural food commodities such as shallots are very vulnerable to seasonal changes, the number of demands and natural conditions that are difficult to control. These situations can have a negative impact on the social, economic and political situation in the country.

Table 1 - Calculation Number of Coefficient Variation of Shallot Prices in Traditional Market of Kupang and Surabaya, June 2016-March 2020 Period

\begin{tabular}{ccc}
\hline Year & CV-Kupang Traditional Market (\%) & CV-Surabaya Traditional Market (\%) \\
\hline 2016 & 19.00 & 13.24 \\
2017 & 30.71 & 25.56 \\
2018 & 27.77 & 20.67 \\
2019 & 29.88 & 21.57 \\
2020 & 24.73 & 22.51 \\
\hline
\end{tabular}

Source: Results of data analysis of shallot prices in Kupang and Surabaya. 
The results of data analysis of shallot price in the 2016-2019 period showed a quite significant disparity. Starting in July 2016 - December 2016 there seems to be an increase in prices, then decreases in September - October 2016, prices rise again in NovemberDecember 2016. In the period of 2017 - 2019 the price disparity continues to increase with the same pattern. This is in line with the increase in fluctuations in the price of shallots as in table 1.

During the middle of 2016 the price of shallots greatly fluctuated, namely CV $19.21 \%$ in Kupang NTT which exceeded the tolerance figure of CV (9\%) while in Surabaya the CV was $13,24 \%$ in the same year. Entering 2017-2019, the price of shallots continues to fluctuate with a CV rate that continues to increase but varies (table 1). Dambe, et al (2019), in their study found that there are differences in price fluctuations between regions and between times. It was further found that the CV rate always went up every year.

Fluctuations in the price of shallots in Kupang and Surabaya between the times (20162020) are very high. When compared between cities, price fluctuations in Kupang are higher than price fluctuations in Surabaya. The difference in CV is because Kupang is a supplied area (deficit area) while Surabaya is a supplier area (surplus), the highest price volatility in both cities (Kupang and Surabaya) occurred in 2017 (30,98\% and 25,56\%). In 2018 the value of CV decreased slightly and in 2019 increased again This CV figure is not much different from the CV that occurred in the past decade, namely the 1995-2011 period as revealed in the BPS report (2018). Research by Rayhan, et al. 2019, found high brinjal price fluctuations in several markets in Bangladesh with CV values reaching 23,52\% - 30,33\%. Jusar, et al (2017) find that price fluctuations are high in the Riau Province of Indonesia with a CV value of $23.05 \%$, high fluctuations due to the economic crisis occurred in 2007-2008.

During the pandemic Covid-19 there was still the probability of the rising of price fluctuations during 2020. This indication began to be seen in the CV value from January to March 2020 of $24,73 \%$ in Kupang and $22,51 \%$ in Surabaya. Zabir, et al (2020) reported that due to the increasing trend of the pandemic Covid-19 and the lockdown situation in Bangladesh, food supply was hampered; and most farmers do not easily adapt to mechanical farming, labour shortages, so that agricultural production is at risk of crop failure. The results of Sömskarand Zapolskaia (2020), found that in the pre-covid-19 period prices volatility increased and fluctuations were high and frequent. It was also found that price fluctuations in the food industry were smaller during co-19 than in the fashion industry. This proves that the manufacturing and transportation industries were more affected during the pandemic Covid-19 than the agriculture sector.

\section{CONCLUSION}

The distribution pattern of shallots trade in NTT province is simpler than in East Java which involves many marketing institutions, including the processed material industry. The largest percentage of shallot production in East Java is directly distributed outside the province, this is different from NTT, the largest percentage is directly distributed to households. The disparity in MPP value in East Java is higher than MPP in NTT, possibly due to differences in distribution, transportation and profit-taking channels between the distribution agencies involved. This condition will be aggravated by the co- 19 epidemic, and will continue if it is not immediately anticipated by the government through the increase in efficiency. A relatively large price disparity of the shallots occurred on a period of time between 2016 - March 2020. The highest price volatility occurred in 2018 in July-September. CV figures of the shallots price in the cities of Kupang and Surabaya annually from 2016 to March 2020 show varying figures per year. The price of shallots in the cities of Kupang (NTT) and Surabaya (East Java) from 2016-2010 was very volatile (high). Price fluctuations that occur in Kupang are lower than in Surabaya. Price fluctuations increased from the pre-covid19 pandemic period due to panic buying and distribution delays due to the implementation of social distancing. The government needs to increase the transparency of price information, improve infrastructure to efficiently distribute commodities, and immediately conduct market operations if there are any indications of price increases. 


\section{REFERENCES}

1. BPS. 2018. Distribusi Perdagangan Komoditas Bawang Merah di Indonesia 2018. Badan Pusat Statistik RI, 2019, Jakarta.

2. Barua, S. 2020. Understanding Coronanomics: The economic implications of the coronavirus (COVID-19) pandemic. SSRN Electronic Journal https://doi org/10/ggq92n.

3. Bonaccorsi, G., Pierri, F., Cinelli, M., Flori, A., Galeazzi, A., Porcelli, F.,... \& Pammolli, F. 2020. Economic and social consequences of human mobility restrictions under COVID19. Proceedings of the National Academy of Sciences, 117(27), 15530-15535.

4. Buheji, M., da Costa Cunha, K., Beka, G., Mavric, B., de Souza, Y. L., da Costa Silva, S. S.,... \& Yein, T. C. 2020. The extent of covid-19 pandemic socio-economic impact on global poverty. a global integrative multidisciplinary review. American Journal of Economics, 10(4), 213-224.

5. Chetty, R., Friedman, J. N., Hendren, N., \& Stepner, M. 2020. How did covid-19 and stabilization policies affect spending and employment? a new real-time economic tracker based on private sector data (No. w27431). National Bureau of Economic Research.

6. Chang, H. H., \& Meyerhoefer, C. 2020. COVID-19 and the Demand for Online Food Shopping Services: Empirical Evidence from Taiwan (No. w27427). National Bureau of Economic Research.

7. Dambe, J., Rukmana, D., \& Mahyuddin, S. N. S. (2019). Volatility Of Rice Prices In South Sulawesi. American-Eurasian Journal Of Sustainable Agriculture, 13(2), 55-60.

8. Douglas, M., Katikireddi, S. V., Taulbut, M., McKee, M., \& McCartney, G. 2020. Mitigating the wider health effects of covid-19 pandemic response. Bmj, 369.

9. Fakari, B., Farsi, M.M., \& Kojouri, M. 2013. Determining Fluctuations and Cycles of Corn Price in Iran. Agricultural Economics/ Zemedelska Ekonomika, 59(8).

10. Garnett, P., Doherty, B., \& Heron, T. 2020. Vulnerability of the United Kingdom's Food Supply Chains Exposed by COVID-19. Nature Food, 1-4.

11. Jusar, D., Bakce, D., \& Eliza, E. (2017). Analisis Variasi Harga Beras di Provinsi Riau dan Daerah Pemasok. Dinamika pertanian, 33(2), 137-144.

12. Kemendag RI. 2015. Rencana Strategis Kementerian Perdagangan RI 2015-2019. Kementerian Perdagangan RI, Jakarta.

13. Nendissa D. R., Anindita R., Hanani N., \& Muhaimin A. W. 2018. Beef Market Integration in East Nusa Tenggara of Indonesia. RJOAS: Russian journal of Agricultural and SocioEconomic Sciences 8(80). August 2018. DOI: 10.18551/rjoas.2018-08.51.

14. Nicola, M., Alsafi, Z., Sohrabi, C., Kerwan, A., Al-Jabir, A., Iosifidis, C.,... \& Agha, R. (2020). The socio-economic implications of the coronavirus and COVID-19 pandemic: a review. International Journal of Surgery.

15. Norouzi, N., de Rubens, G. Z., Choubanpishehzafar, S., \& Enevoldsen, P. (2020). When pandemics impact economies and climate change: Exploring the impacts of COVID-19 on oil and electricity demand in China. Energy Research \& Social Science, 68, 101654.

16. Ozili, P. K., \& Arun, T. 2020. Spillover of COVID-19: impact on the Global Economy. Available at SSRN 3562570.

17. Pusdatin, 2017. Outlook Komoditas Subsektor Hortikultura. Outlook Bawang Merah. Pusat Data dan Informasi Pertanian, Kementan RI 2016, Jakarta.

18. Rayhan, S. J., Islam, M. J., Kazal, M. H., \& Kamruzzaman, M. 2019. Market Integration and Seasonal Price Variation of High-Value Vegetable Crops in Chittagong Hill Districts of Bangladesh. International Journal, 6(3), 150-165.

19. Sömskar, A., \& Zapolskaia, Z. 2020. Short Term Effects of Covid-19 on Stock Market Performance-a Comparison of the Fashion and the Food Industry: A Study on How Volatility and the Expected Return Affect the Share Price.

20. www.faostat.fao.org diunduh 5 Maret 2020

21. Zabir, A. A., Mahmud, A., Islam, M. A., Antor, S. C., Yasmin, F., \& Dasgupta, A. 2020. COVID-19 and Food Supply in Bangladesh: A Review. Available at SSRN 3595967. 